\title{
A DIGITALIZÁCIÓ FEJLŐDÉSÉNEK HATÁSA A POLGÁRI PERBELI BIZONYÍTÁSRA
}

\author{
Zámpori Anna \\ PhD hallgató, Miskolci Egyetem, Nemzetközi Jogi Intézet, Polgári Eljárásjogi Tanszék \\ 3515 Miskolc, Miskolc-Egyetemváros, e-mail: anna.zampori@gmail.com
}

\begin{abstract}
Absztrakt
Az elektronikus-digitális rendszerek bevezetése és folyamatos fejlesztése, korunk egyik legdinamikusabban fejlődö területe, jelen van életünk szinte minden területén. Alkalmazásuk napjainkra evidenssé vált a mindennapos ügyintézés során és már a jogi eljárásokban is. A mesterséges intelligencia és a digitalizáció különbözö jogászi tevékenységtípusokban, illetöleg különbözö jogterületeken és jogintézményekkel kapcsolatos megjelenését és hatását manapság sokan és sokféle szempontból elemzik, a felmerülö problémák köre rendkivül szines és szinte végtelen. Jelen tanulmány a digitalizációnak a polgári perbeli bizonyitásra gyakorolt hatásait teszi vizsgálat tárgyává.
\end{abstract}

Kulcsszavak: polgári eljárásjog, digitalizáció, bizonyitás, technikai fejlődés, jog, számitástechnika és jog, mesterséges intelligencia

\begin{abstract}
The introduction and development of the electronic-digital systems is one of the most dynamically evolving field of our time, also being present in our everyday life. The utilization of such systems have become evident in our day-to-day administration, and it also applies to the legal proceeds. Analyzing the effect of artificial intelligence and digitalization on different types of legal activities, areas of law and the appearance in legal institutions has been subject to many, the range of problems that arise is extremely diverse and almost infinite. In this study I would like to examine the effects of digitization on civil litigation evidence.
\end{abstract}

Keywords: civil procedure law, digitalisation, litigation evidence, technical development, law, computer technology and law, artifical intelligence

\section{Bevezetés}

A technikai vívmányok széleskörủ elterjedése, használatuk mindennapossá válása, az informatika és a számítógépes hálózatok robbanásszerü fejlődése vonatkozásában közhelynek számít napjainkban, ha azt mondjuk, az élet minden területére hatással vannak, hiszen mindannyian tapasztaljuk, milyen módon változtatják meg mindennapjainkat és szokásainkat a különböző elektro-, és számítástechnikai eszközök. Jelen tanulmány elkészítését számos tudományos munka előzte meg, amelyek a számítástechnika-, digitalizáció-, vagy a mesterséges intelligencia fejlődésének jogi aspektusait vizsgálták egyegy jól lehatárolható kérdéskör vonatkozásában, és igyekeztek valamilyen tendenciát felvázolni a fejlődés lehetséges ívét illetően a rendelkezésre álló információk és tapasztalatok alapján. Éppen ezért jelen tanulmány nem kíván előrevetíteni lehetséges jövőképet a digitalizáció igazságszolgáltatásra gyakorolt hatásai tekintetében, csupán egyfajta összegzést, áttekintést kíván adni a tapasztaltakról a polgári perbeli bizonyításra gyakorolt hatások tekintetében. 
Az elmúlt években jelentős fejlődésen ment keresztül a bírósági eljárás, nem csupán az új polgári perrendtartás hatályba lépése okán, hanem többek között a digitalizáció nyújtotta elönyök és annak eredményeképpen megszülető eszközök széles társadalmi rétegek által történő mindennapi használata miatt is. Ugyanakkor a SARS-CoV-19 humán egészségügyi járványhelyzet miatt kihirdetett veszélyhelyzet idején alkalmazott rendhagyó eljárásjogi szabályok rávilágítottak némi hiátusra is a pozitív tapasztalatok mellett gyakorlati alkalmazásuk során a felhasználói társadalom tagjait illetően, továbbá az online tárgyalások kapcsán is. Mégis azt lehet mondani, hogy ez a rövid idejü „teszt-üzem” a pozitívumok és hiányok megfelelő értékelése mellett képes lehet adott esetben a fejlődésnek megfelelő irányt mutatni.

Az informatikai és számítástechnikai fejlődés folyamatossága gyakorlatilag állandó aktualitást kölcsönöz a digitalizációval kapcsolatos tudományos igényű munkáknak, még az állam- és jogtudomány müvelöi esetében is. Annál is inkább, hiszen ezen tudomány - jellegénél fogva - szerves kapcsolatban áll a társadalommal és annak változásaival, így kénytelen azokat lekövetni és igyekeznie kell lépést tartania ezen változásokkal is a megfelelő alkalmazhatóság és jogvédelem megteremtése érdekében. Szükségképpen reagálnia kell hát a számítástechnika évek óta tartó exponenciális fejlődése jelentette számos előnyre és kihívásra egyaránt, valamint - igazgatási és ügyintézési aspektusból vizsgálva - a digitalizáció elterjedése okán megváltozó „felhasználói” igényekre is. Bár látszólag a digitalizáció igazságszolgáltatásra gyakorolt hatása szempontjából vizsgálva közvetlen kapcsolódási pontok vélhetően egyelőre nem lelhetőek fel a COVID-19 vírus okozta járványhelyzet miatt a közoktatási-, valamint felsőoktatási intézményeben bevezetett online oktatás között, meglátásom szerint mindenképp érdemes lesz néhány gondolatot szentelni a témakörnek ebből a szemszögből is. Nem lehet ugyanis elmenni amellett a nem elhanyagolható társadalmi jelenség mellett, hogy felnőtt egy generáció, akik a számítógéppel már egészen kicsi gyermekkorukban találkoztak, használták és a mindennapjaik szerves részét képezik mind a mai napig. Tovább füzve a gondolatot, napjainkban pedig felnövekvőben vannak annak a generációnak a tagjai, akik ugyancsak egészen kicsi gyermekkoruktól kezdődően találkoztak és használják az ún. „okos-készülékeket” és napjainkban a mindennapjaik szerves részét képezik. Meglátásom szerint ezek a jelenségek mind-mind befolyásolják a majdani felhasználói igények változásának irányát, (az információs társadalom lehetséges fogalommeghatározását ld. bővebben: Czékmann, 2016) így szükségszerüen halaszthatatlanná teszi a bíróságok és a peres felek közötti kommunikációs csatorna megreformálását is. Többek között a digitalizáció, valamint a számítástechnikai eszközök rapid elterjedésének köszönhetően változott a polgári perbeli bizonyítási eljárás is. Ezek a változások szükségszerüen hozták magukkal azt az igényt - mind igazgatási, mind pedig „,felhasználói oldalról” nézve -, hogy a fejlődés által biztosított előnyök a bírósági eljárások, valamint az adminisztrációs folyamatokban is hasznosításra kerüljenek.

\section{Civilisztikai szemléletű fejlődéstörténeti áttekintés}

Le kell szögezni, hogy a közigazgatásban és az igazságszolgáltatásban a technika vívmányainak mind szélesebb körben történő hasznosítására való törekvés, valamint a digitalizáció hatásaira történő megfelelő reagálás nem újkeletủ jelenség. Számos tudományos igényü munka is született a témakörben a tanulmányoktól a monofográfiákon keresztül a tematikus konferenciákon át, amelyek hatására számos technológiai megoldás már a gyakorlatban is alkalmazásra került. A teljesség igénye nélkül néhány főbb állomáspontot érdemes áttekinteni. Így rögtön első mérföldkőként megemlíthetjük ehelyütt a 2008-ban még nagy változásnak ható teljesen elektronizált cégeljárást. Magyarország az uniós tagállamok közül az elsők között hozta meg az elektronikus cégeljárásról és a cégiratok elektronikus úton 
történő megismeréséről szóló jogszabályt, amely biztosítja a cégek számára azt a jogi lehetőséget, hogy a bejegyzési (és változásbejegyzési) kérelmet elektronikus úton nyújthassák be a cégbíróságnak. (Kapa, 2007) Meg kell azonban jegyezni, hogy nem véletlenül zajlott ez le elöször éppen a cégeljárások vonatkozásában. Ebben a gazdasági szereplők elvárásain túl nagy jelentőséggel bírt az is, hogy a cégeljárás - az egyéb bírósági eljárásokkal szemben - nem kontradiktórius, hanem egyoldalú kérelmeken alapul, továbbá kötelező a jogi képviselet, a jogi képviselök (és a cégbírók) elektronikus aláírás használatával járnak el. Ezért itt nem jelentkeznek azok a rendszerinti nehézségek, amelyek miatt az egyéb, kontradiktórius bírósági eljárásokban a beadványok elektronikus benyújtásának lehetőségére 2013-ig várni kellett. (Tóth, 2021)

A polgári peres eljárásokban hosszú ideig elképzelhetetlennek tünt az elektronikus kapcsolattartás bevezetése. Részben mert az eljárási törvények nem tartalmazták ennek kereteit, részben pedig a bírósági, illetve a bíróságon kívüli informatikai infrastruktúra sem volt erre feltétlenül alkalmas. (Weidinger, 2015) Mindezek az okok és sajátosságok együttesen vezettek oda, hogy a polgári eljárásokban fokozatosan került sor az elektronikus ügyintézés bevezetésére.

Az elektronikus kapcsolattartás 2013. január 1. napjától kezdődően vált opcionális kapcsolattartási móddá, (A polgári perrendtartásról szóló 1952. évi III. törvény (a továbbiakban: rPp.) "Elektronikus kommunikáció a polgári perben" című XXVIII. fejezetét a 2009. évi LII. törvény vezette be 2010. január 1-jei hatállyal, amelyet többszöri jogszabály-módosítás követett.) de kizárólag a törvényszékek elsőfokú civilisztikai pereiben. 2015. július 1. napjától már lényegesen szélesebb körben nyílt erre lehetőség, hiszen ezen időponttól az elektronikus kapcsolattartás valamennyi járásbíróság és törvényszék első- és másodfokú peres ügyében választható eljárási mód lett. A beadványok elektronikus benyújtásához, kezeléséhez, feldolgozásához, határozatok létrehozásához, kiadmányozásához, a bíróságok és más szervek egymás közötti elektronikus kapcsolattartásához, az illeték elektronikus megfizetéséhez szükséges feltételek több projekten keresztül, több év során teremtődtek meg és e folyamat máig is tart. A civilisztikai eljárásokban a döntő változást 2016. július 1. napja jelentette. Az ezt követően indult polgári perekben és törvényi rendelkezés alapján más polgári eljárásokban, valamint a közigazgatási és munkaügyi perekben az addig választható elektronikus kapcsolattartás kötelezővé vált a személyesen eljáró feleken kívül tulajdonképpen minden más eljárási szereplö számára. (Az elektronikus ügyintézés és a bizalmi szolgáltatások általános szabályairól szóló 2015. évi CCXXII. törvény (a továbbiakban: E-ügyintézési törvény) 1 . §-a alapján)

Az E-ügyintézési törvény 2015-ben történt kihirdetésekor a Pp. kodifikációja még folyamatban volt, amelynek egyik fontos eleme a törvényszéki perrend bevezetése volt. (Ami azt jelentette, hogy a Pp. általános szabályait a törvényszék előtt, kötelező jogi képviselet mellett folyó perekre modellezték.) Az E-ügyintézési törvény rendelkezéseiből (E-ügyintézési törvény 9. §) az következik, hogy a törvényszék előtt folyó perekben a jogi képviselők számára az elektronikus út kötelező, azaz minden beadványt, bizonyítékot kizárólag elektronikusan nyújthatnak be. A jogalkotó a rPp. (1952-es Pp.) megoldását követve a Pp.-ben (2016. évi CXXX. tv.) is külön részben, külön fejezetben helyezte el az elektronikus kapcsolattartás szabályait. A Pp. indokolása szerint a törvény az egyes jogintézmények tekintetében nem kívánt külön eljárásrendet bevezetni attól függően, hogy a kapcsolattartás papíralapon, vagy elektronikus úton történik-e egy adott eljárásban. Erre figyelemmel a jogalkotó az elektronikus kapcsolattartás szabályait is tartalmazó külön fejezetben kizárólag azokat az előírásokat helyezte el, amelyek az elektronikus kapcsolattartás sajátossága folytán az általános szabályoktól eltérő rendezést igényeltek. (Indokolás a 604. §-hoz.)

Az E-ügyintézési törvény 2018. január 1-jén hatályba lépett rendelkezései az elektronikus ügyintézési szolgáltatásokat úgy szabályozták, hogy az elektronikus kapcsolattartás általános szabályait keretjelle- 
gủ rendelkezésekkel írták elő. A törvény indokolása szerint ez többek között azt a célt szolgálta, hogy az ügyfelek széles körének ügyintézési szolgáltatásokat nyújtó állami és nem állami szervezeteket egységes elvek mentén történő elektronikus ügyintézésre szorítsa. (E-ügyintézési törvény 1 . $§ 17$. pontja) Elengedhetetlen volt az elektronikus ügyintézés szempontjából a differenciálatlan szabályozás kialakítása az informatikai hálózatok megfelelő kapcsolódásának megteremtése érdekében. Ugyanakkor a bíróságok elött folyó eljárások kontradiktórius jellegéből fakadóan voltak/vannak technikai nehézségek (pl.: jelentősebb mennyiségü kép, esetleg nagyméretü hang- és képfelvételt tartalmazó beadványok elektronikus benyújtásához adottak-e a feltételek?), amelyeket áthidalni szükséges az alapvetően kérelemre induló eljárásokra domborított elektronikus kapcsolattartásra vonatkozó szabályozást illetően.

Elvitathatatlan tény, hogy az elmúlt évtizedekben a magyar igazságszolgáltatás igazgatási része jelentősnek mondható technikai fejlődésen ment keresztül. Megjelent például a Via Video rendszer, amely lehetővé teszi az elektronikus úton történő tanúvallomás megtételét, kiválta a személyes megjelenéssel járó kellemetlenségeket. (ifj. Lomnici, 2020) Kiemelést érdemel a Lajstromirodai Iratbetekintő Rendszer, az e-akta, valamint az Ügyfél Irathozzáférési Rendszer (ÜIR). Ez utóbbi esetében meglátásom szerint az igénybevétele szempontjából üdvözlendő, hogy a Kormányzati Azonosítási Ügynökön (KAÜ) keresztül történik (e-személyiigazolvány együttes alkalmazása mellett) az azonosítás, hiszen az „ügyfélkapun” keresztül történő ügyintézés egy már „,bejáratott” ügyintézési útnak tekinthető. A bírósági tájékoztató (eakta.birosag.hu) alapján sikeres azonosítás, valamint az ügyhöz tartozó és a kérelemben foglalt adatok egyezősége esetén az ÜIR a betekintési kérelmet automatikusan jóváhagyja, amelyről az ügyfelet egy szintén automatikusan generált rendszerüzenet tájékoztatja. Egyetlen nehézséget véltem felfedezni az ÜIR használatát illetően, mégpedig az e-személyi igazolvánnyal történő azonosítást, ehhez ugyanis egy erre a célra szolgáló kártyaolvasó berendezés is szükséges, amely jelen tanulmány elkészülése idején koránt sem tekinthető alapvető használati tárgynak ügyfél oldalon.

A számítástechnikai eszközök elterjedésének és töretlen fejlődésének az igazságszolgáltatásra gyakorolt hatásain végig tekintve arra a következtetésre juthatunk, hogy a cégeljárások elektronikussá válásától eltelt szük 15 esztendő alatt rendkívül nagy utat tettünk meg. Az egyszerü igazgatási/adminisztratív feladatok puszta automatizálásától napjainkra meghatározó kérdéssé nőtte ki magát a mesterséges intelligencia igazságszolgáltatásan történő alkalmazhatóságának a feltételrendszerének megteremtése, míg egyes országokban bizonyos esetekben már alkalmazzák is. Észtország már meg is alkotta a világ első robot-bíráját, és már bárki számára elérhető a világhálón a Chatbot nevü alkalmazás, mely jogi tanácsokat osztogat a hozzá fordulóknak. (Balogh, 2019) Argentínában például megalkotásra került a "Prometea AI" elnevezésü intelligens program. A telefonon felhívható szoftver képes arra, hogy egy ügyiratszám alapján határozat-tervezeteket készítsen, korábbi precedenseket mérlegelve akár a bírósági ítélet tartalmára is tud javaslatot megfogalmazni. A program egyszerübb jogi megítélésü ügyekben képes automatizálni az igazságszolgáltatási eljárásokat a megfelelő jogi nyelvezet használatával. (Molnár, 2019)

Az Európai Unió Bizottsága 2018. december 7-én „A mesterséges intelligenciáról szóló összehangolt terv" címmel közleményt adott ki, amely felvázolja a terv fö céljait és kezdeményezéseit. Az öszszehangolt terv arra az együttmúködési nyilatkozatra épít, amit Norvégia és a tagállamok írtak alá 2018 áprilisában a Digitális Napon. A tagállamok ezen nyilatkozattal kinyilvánították azt, hogy közösen kívánnak fellépni az AI kutatása, alkalmazása, fejlesztése és jogi szabályozása érdekében. A nyilatkozattal összefüggésben a visegrádi tagországok külön állásfoglalást tettek közzé, hangsúlyozva, hogy a jövőben a mesterséges intelligenciával kapcsolatos fejlesztéseket továbbra is ösztönzik, ez is jól mutatja a Digitális Napon aláírt nyilatkozat jelentőségét. 
Kétség nem fér ahhoz, hogy a mesterséges intelligencia fejlesztése hatalmas mennyiségü adatot igényel (vö. Zödi, 2017), így a közös európai adattér kialakításával egy olyan biztonsági háló kerülne kialakításra, amely a közszféra és a vállalkozások közötti tevékenységek céljára az adatokat összefogja, s azokat elérhetővé teszi. (Molnár, 2019) Arról nem is szólva, hogy a jelenség sajátosságainál fogva országhatárokon átívelő módon képes kifejteni hatását, így a közös standardok kialakítása elengedhetetlennek tünik.

\section{Tapasztalatok a veszélyhelyzet ideje alatt és abból levont következtetések}

A doktori kutatásom során alapvetően a személyiségvédelem polgári perjogi aspektusaival foglalkozom, melynek során kiemelt jelentősége van a bizonyítási eljárásra vonatkozó szabályanyagnak, amelyre szükségszerüen hatást gyakorol a digitalizáció, hiszen szerteágazó jellegénél fogva számos technológiai változást indukál. Ezek a változások - egyetértve Ződi Zsolttal -, egy idő után elkezdik átalakítani azokat a szférákat, amelyekbe egyre jobban behatolnak.

A jogban a digitalizáció eleinte nem ígért többet csak "papírmentes" irodát, amelyben az iratokat nem kell kinyomtatni és postán küldeni, így gyorsabbá lehet tenni az iratmozgást, és költséget lehet megtakarítani. Hamar kiderült azután, hogy a digitális szöveglétrehozás lehetővé teszi, hogy az ügyfelek eleve bizonyos információkat adatként, strukturált információként elektronikus ürlapokon adjanak be. Ekkor kezdték el egyre több eljárásban vizsgálni, hogy melyek azok a mozzanatai a processzusnak, ahol nincsen emberi döntés, beavatkozás, hiszen ezeket könnyüszerrel lehet azután nagyrészt, vagy akár teljesen automatizálni is. Ahhoz azonban, hogy az automatizálás hatékony legyen az eljárási és anyagi jogi szabályokat fel kell dolgozni és szoftverekbe kell zárni, amelyek azután irányítják majd az eljárások lefutását, majd magukat ezeket a szabályokat is meg kell változtatni. (Ződi, 2018)

Noha a „papírmentes irodától” messze eljutottunk, korántsem mondhatjuk - véleményem szerint azt, hogy látnánk derengeni a fényt az alagút végén, annak ellenére sem, hogy hazánkban is egyre többeket ihlet meg a mesterséges intelligencia igazságszolgáltatásban való alkalmazhatóságának egyes kérdéseinek témaköre, mint az egyik a digitalizáció oly sok hozadéka közül. A magam részéröl úgy gondolom, hogy elengedhetetlen a tényekhez ragaszkodva szembesíteni magunkat azzal, hogy hol is tartunk a fejlődésben a digitalizációt illetően perjogi aspektusból is ahhoz, hogy olyan célokat tudjunk kitüzni magunk elé, amelyek belátható időn belül válhatnak biztonsággal és kiszámítható módon akár széles körben is - alkalmazhatóvá. Mert bár más országokkal történő összehasonlítás útján is mérhető hazánk digitalizációs szempontból bejárt fejlődési útja, azt gondolom, hogy a digitalizálódás tendenciáit befolyásoló egyes tényezőkön (ld. bővebben: Ződi, 2018) túl szükséges figyelemmel kísérni hazánk egyedi társadalmi sajátosságait is. Úgy vélem, hogy a tavalyi évben a COVID-19 vírus okozta humán-egészségügyi világjárvány miatt kihirdetett veszélyhelyzet (40/2020. (III. 11.) Korm. rendelet) okán a 74/2020. (III. 31.) Korm. rendelet - vagy más néven Veir. - által bevezetett eljárási renddel kapcsolatos tapasztalatok érdekes fokméröi lehetnek a jelen gondolati egység által is boncolgatott „hol is tartunk?” kérdés tekintetében.

Számos változást eszközölt a jogalkotó a peres eljárások vonatkozásában, amelynek következtében az egyébként személyes jelenlétet igénylő (közvetlenség elvéből fakadóan) és a szóbeliség elvét is sajátjának tekintő peres eljárás teljes egészében az írásbeliség felé tolódott el annak ellenére, hogy a Veir. a személyes jelenlét problematikáját a személyazonosításra alkalmas (jellemzően kép és hang egyidejű továbbítására alkalmas eszköz) elektronikus eszköz útján, a távmeghallgatáshoz hasonló módszerrel kívánta áthidalni. (Zámpori, 2020) A jelen tanulmány bevezetésében az információs társadalommal kapcsolatban tett megállapítások ellenére az esetek döntő többségében azért került online 
tárgyalás megtartása helyett a peres felektől írásbeli nyilatkozatok beszerzésére sor, mert úgy nyilatkoztak, hogy nem biztosítottak az online tárgyalás feltételei a részükröl (nem rendelkeznek e-mail címmel, valamint kép és hang egyidejü továbbítására alkalmas számítástechnikai eszközzel, internet kapcsolattal, Skype business alkalmazással).

A dolgozatom elején azt a megállapítást tettem, hogy gyakorlatilag egy generáció már felnőtt, akinek a gyermekkorától kezdődően a mindennapjai részét képezte és képezi a mai napig is a számítógép, míg felnövekvőben van egy generáció, amelynek a tagjai szinte csecsemő koruktól kezdve találkoznak nap mint nap az „okos eszközökkel”. Kitértem a felhasználói igények megváltozására is többek között, amely vonatkozásában ugyancsak elöremutató tendenciákat vélhetünk felfedezni, és amelyeket a pandémiás időszak ugyancsak az online ügyintézés medrébe igyekezett mindinkább becsatornázni. A peres eljárások esetében tapasztaltak ugyanakkor rácáfolni látszanak ezekre a megállapításokra, ugyanis a veszélyhelyzeti eljárásrend - számos pozitív hozadéka ellenére - többek között arra is rámutatott a gyakorlatban, hogy a polgári perek alanyainak többsége még mindig elmaradásban van az informatikai feltételek biztosításában: alapvetően a gyakorlatban ezt támasztotta alá az e-tárgyalások csekély száma és az a jogalkalmazói törekvés, mely az írásbeli nyilatkozatokat részesítette előnyben. A hiányosság egyrészről tetten érhető a tárgyi eszközök terén, másrészről a jogalkalmazók informatikai képzettségét illetően is. A korszerütlenségből adódó nehézségek ugyanis önmagában azzal nem küszöbölhetők ki, hogy minden bírósági tanács kap egy laptopot, amely webkamerával és mikrofonnal van ellátva, vagy korszerübb számítástechnikai eszközökkel felduzzasztják a bírósági informatikai rendszert, különös tekintettel arra, ha az egyik szereplőnek biztosítjuk a feltételeket, de a másik szereplő (felperes vagy alperes) számára továbbra is akadályt jelent a technikai feltételek biztosítása, úgy továbbra sem oldódott meg az infrastrukturális problematika. Ettől függetlenül elengedhetetlen, hogy ezen a téren is megfelelő előkészületek előzzék meg az ,átállást”.

Mindent összevetve a valósághoz meglátásom szerint sokkal közelebb áll a bevezető gondolatok között tett megállapítások az információs társadalmat illetően és a veszélyhelyzet idejére bevezetett online tárgyalással összefüggésben tapasztaltak döntő többségében inkább tudhatók be az online tárgyalással szemben tanúsított szkeptikus hozzáállásnak, vagy a Pp.-ben alapelvi szinten rögzített rendelkezési jog sajátos gyakorlásának, semmint a korábban részletezett technikai feltételek hiányosságának, vagy teljes hiányának. (vö.: Németh, 2021)

\section{A digitalizálódó bizonyítási eljárás egyes kérdései az új Pp. szabályozásának tükrében különös tekintettel a titokban készült kép- és hangfelvételek vonatkozásában}

A társadalmi és gazdasági viszonyok átalakulása arra felé tendál, hogy egyre több alkalommal jönnek létre információ aszimmetrikus helyzetek, amelyek megnehezítik egyik vagy másik fél bizonyítását az eljárás során. A számítástechnikai eszközök elterjedésének, és széles társadalmi rétegek által hozzáférhetővé válása - mint a digitalizáció egyik (mellék)hatása -, lassanként megváltoztatni látszik a bizonyítékok „előállítását” is a polgári perek tekintetében. Az új Pp. 267.§-a rögzíti a bizonyítás módjait, amelyben bár felsorolja annak lehetséges módjait, a jogszabályhely második fordulatában foglaltak a látszólag taxatívnak tünő felsorolást példálózóvá teszik, amely ezáltal a felsoroltakat meghaladóan bármilyen „egyéb” bizonyítási módot is foganatosíthatónak tekint, ha a perben jelentős tények megállapítására alkalmas és a jogvita eldöntése szempontjából célszerünek mutatkozik, kivételt képeznek ez alól az olyan módozatai bizonyításfelvételnek, amelyek a közrendbe ütköznek. A 268.§ (2) bekezdése sorolja fel a bizonyítási eszközöket ugyancsak példálózó jelleggel, míg a 269.§ rendelkezik a jogsértő bizonyítási eszközök eljárásjogi sorsáról. Állápontom szerint a jogsértő bizonyítási eszközök egyre 
nagyobb számban való megjelenése egyfajta társadalmi reakció, amely részben betudható a digitalizáció hatásának, másrészt viszont az információ aszimmetrikus helyzetek elszaporodása is egyre inkább tereli abba az irányba egyik vagy másik peres felet, hogy kénytelen legyen ilyen jellegü bizonyítási eszközt igénybe venni állításai alátámasztására vagy az ellenérdekủ fél állításainak cáfolása céljából.

Rögzíthető az is, hogy a polgári eljárások során egyre növekvő arányban találkozhatnak a bíróságok jogsértő bizonyítási eszközökkel. A növekvő tendencia alapján, valamint a megváltozott jogszabályi hátterek hatására indokolttá vált, hogy az eljárásjogi kódex is megújuljon. Ahhoz, hogy a társadalmi és technikai fejlődés követelményeinek megfeleljen számos újítást vezetett be a jogszabály, ilyen újításnak tekinthető a 269.§-ban foglalt szabályozás is. A bíróságok az adat-, kép-, és hangrögzítésre alkalmas technikai eszközök rapid elterjedésével egyre nagyobb számban előforduló jogsértő bizonyítékok jogi kezelésére az eltelt évek alatt nagyjából egységes eljárási rendet alakítottak ki, azonban lényeges eltérések lehetnek különböző bíróságok ítéletei között. Mindenképp szükségessé vált egy konkrét szabály kidolgozása ezen esetekre, amely kellően rugalmas a peres ügyek által felvonultatott élethelyzetek sokszínüségére tekintettel, amelyet az azóta eltelt idő alatt született bírósági döntések is alátámasztani látszanak. (BDT2018.3877.; Pf.20.781/2018/4.; 3312/2017. (XI.30.) AB határozat)

\section{5. Összegző gondolatok}

A digitális forradalom a polgári pert sem kerüli el. Sőt, mivel a polgári per egyik alapelve az ügyfeleket megillető rendelkezési elv, hatványozottan és egyre inkább meg fog jelenni a polgári pereket elbíráló jelenlegi bírósági rendszeren az az ügyfélnyomás, ami gyors, egyszerü és költséghatékony polgári eljárást igényel. (ld.: Németh, 2021) Látható, hogy a digitalizáció hatásai hatást gyakorolnak egyrészt az adminisztratív jellegü tevékenységekre, de változást idéznek elő eljárásjogi szempontból is. A jogsértő bizonyítási eszközök és a bizonyítási eljárás változásai is mind a jelen tanulmányban boncolgatott digitalizáció átformáló hatásainak egyik példájaként említhetőek. Az arra adott jogalkotói reakcióról pedig elmondható, hogy a tapasztalatokkal és a joggyakorlattal is koherens szabályozás megteremtésével igyekszik lépést tartani a gyors ütemben változó igényekkel. A fejlődés iránya és üteme arra felé tendál, hogy a digitális forradalom kicsúcsosodását a mesterséges intelligencia alkalmazása fogja jelenteni az igazságszolgáltatásban. Kérdéses azonban, hogy mekkora teret fog kapni és mennyiben lesz képes adott esetben helyettesíteni is a jogászi hivatásrendek egyes képviselőit. (Ld bővebben: Nagy, 2020) Napjainkban már kifejezetten érdekes és a majdan kialakítandó szabályozás vonatkozásában elöremutató tanulmányok születnek a témakörben, (vö.: Lőrinc, 2019; Pusztahelyi, 2020; Juhász, 2020; Bordács, 2020; Máté és társai, 2020) figyelemmel kísérve a környező országok kutatásait és a digitalizációval kapcsolatban elért eredményeit, jó gyakorlatait, esetleg a kialakított gyakorlatok hátrányait.

A jelen dolgozat vonatkozásában elmondható, hogy csupán szemezgetett a rendelkezésre álló és már most is rendkívül terjedelmes szakirodalomból, amelynek csupán egy szeletét vizsgálta. Ennek során igyekezett koncepcionálisan a polgári eljárásjogra domborítani a tapasztalatokat. Összességében azt lehet mondani, hogy a jogalkotói oldalról az igyekezet megvan arra nézve, hogy minél inkább az információs társadalom által diktált online tér felé el lehessen tolni a peres eljárásokat is, amelynek köszönhetően további idő és költség spórolható meg. A számítástechnikai eszközök bár széleskörben elterjedtek és hazánkban is lakosság arányosan nagy létszámban használjuk napi szinten, álláspontom szerint, ha adott esetben máról holnapra kellene teljes egészében átállni az online bírósági tárgyalásra, nagy valószínűség szerint többen lennének, akiknek sérülne a bírósághoz való forduláshoz füződő alapvető joga (vagy legalábbis erre a következtetésre jutnának), mint akiknek nem. Bár a veszélyhely- 
zetben bevezetett online tárgyalásokat illetően vannak egyes kérdéseket illetően fenntartásaim, általánosságban elmondható, hogy a körülményekhez képest jól vizsgázott, s botorság volna tagadni, hogy a jövő nem az online tárgyalásoké volna. (vö.: Németh, 2021)

Egyetértve ugyanakkor Balogh Juditnak a mesterséges intelligencia igazságszolgáltatásban betöltött funkciójával kapcsolatban megfogalmazott gondolataival, „nem az a kérdés, hogy van-e létjogosultsága ebben az ágazatban, hanem hogy mikor és mennyiben formálja át az egyes szerepköröket. A jelenleg kifejlesztett és alkalmazott technológiai megoldások máris hatást gyakoroltak a bíróságok munkamódszerére: bizonyos értelemben tehermentesítést eredményeznek, hiszen emberi közremüködés nélkül támogató funkciókat látnak el, megjósolják a jogvita lehetséges kimenetelét, mellyel a bíróságon kívüli vitarendezést is ösztönzik.

A mesterséges intelligencia alkalmazható az igazságszolgáltatás egyes területein, segítségével időt nyerhetünk bizonyos - kevésbé érdekes, inkább technikai jellegü - munkamozzanatok automatizálásával (pl. nyomtatványok kitöltése vagy bírósági határozatok kigyüjtése). Ám jelen pillanatban kijelenthetjük, hogy a mesterséges intelligencia nem alkalmas jogi kérdésekben döntések meghozatalára, ezért egyhamar nem fogja helyettesíteni az ügyvédeket és a bírákat.” (ld: Balogh, 2019)

\section{Köszönetnyilvánítás}

A cikkben ismertetett kutató munka az EFOP-3.6.1-16-2016-00011 jelü „Fiatalodó és Megújuló Egyetem - Innovatív Tudásváros - a Miskolci Egyetem intelligens szakosodást szolgáló intézményi fejlesztése" projekt részeként - a Széchenyi 2020 keretében - az Európai Unió támogatásával, az Európai Szociális Alap társfinanszírozásával valósul meg.

\section{Irodalom}

[1] Czékmann, Zs. (2016). Információs társadalom és elektronikus kormányzat Magyarországon. $\mathrm{PhD}$ értekezés. Miskolc 17-18.

[2] Kapa, M. (2007). A magyar polgári eljárásjog fejlődési tendenciái - különös tekintettel az elektronikus polgári eljárásra. De iurisprudentia et iure publico - Jog- és politikatudományi folyóirat, 2007(1-2), 10-23.

[3] Tóth, G. (2021). Az elektronikus kapcsolattartás szabályai a polgári eljárásokban a kodifikáció tükrében. Jogtudományi Közlöny, 2021(6), 297-304.

[4] Weidinger, P. (2015.10.25.). Elektronikus pert hoz az új esztendö. https://arsboni.hu/elektronikus-pert-hoz-az-uj-esztendo/

[5] Lomnici, Z. (2020.02.10.). A mesterséges intelligencia megjelenése az igazságügyi rendszerekben - jönnek az online tárgyalások?

http://alaptorvenyblog.hu/blog/a_mesterseges_intelligencia_megjelenese_az_igazsagugyi_rend szerekben_jonnek_az_online_targyalasok

[6] https://eakta.birosag.hu/\#

[7] Balogh, J. (2019.07.02.). M.I vs J.O.G - Azaz "mesterséges intelligencia" versus "jogászság okos generációja". https://arsboni.hu/m-i-vs-j-o-g/

[8] Molnár, O. (2019.07.01.). "Hasta la vista, baby". https://arsboni.hu/hasta-la-vista-baby/

[9] Ződi, Zs. (2017). Jog és jogtudomány a Big Data korában. Állam és Jogtudomány, 2017(1), 95114.

[10] Ződi, Zs. (2018). A digitalizáció hatása a jogászi szakmára. Gazdaság és Jog, 2018(12), 4-5.

[11] Zámpori, A. (2020). Polgári perek a veszélyhelyzet idején. Miskolci Egyetem, Doktoranduszok 
Fóruma, ÁJK Szekciókiadvány.

[12] Németh, Cs. (2021). A digitális bírósági tárgyalások eljárásjogi és alkotmányjogi vonatkozásai a polgári peres eljárásokban - Javaslatok a digitális bírósági tárgyalások bevezetésére Magyarországon. Gazdaság és Jog, 2021(2), 1-9.

[13] Nagy, A. (2020). A mesterséges intelligencia és a digitalizáció jelentősége és lehetséges hasznosítási területei az igazságszolgáltatásban. Infokommunikáció és Jog, E-Különszám

[14] Lörincz, Gy. (2019). A mesterséges intelligencia alkalmazásával hozott döntés jogi megítélésének egyes kérdései. Gazdaság és Jog, 2019(4), 1-7.

[15] Pusztahelyi, R. (2020). Mesterséges Intelligencia által okozott károk: a no-fault kártalanítási rendszer bevezetésének előnyei és hátrányai. Infokommunikáció és Jog, E-Különszám

[16] Juhász, Á. (2020). Online szerződéskötés, digitális tartalom és szolgáltatás, intelligens szerződések - A szerződési jog új korszaka? Infokommunikáció és Jog, E-Különszám

[17] Bordács, B. (2020). Az algoritmusok alkalmazásának versenyjogi vonatkozásai - joggyakorlat és szabályozási kérdések. Gazdaság és Jog, 2020(9), 7-12.

[18] Máté, D. A., Mélypataki, G., Rácz, Z. (2020). A mesterséges intelligencia alkalmazásának hatása a munkához és a szociális biztonsághoz való jogra. Infokommunikáció és Jog, 2020(1), 38. 